\title{
Thyroid Gland Hemangioma
}

National Cancer Institute

\section{Source}

National Cancer Institute. Thyroid Gland Hemangioma. NCI Thesaurus. Code C156343.

A rare hemangioma that arises from the thyroid gland. 